\title{
Meiobenthic interactions with macrobenthic larvae and juveniles: an experimental assessment of the meiofaunal bottleneck*
}

\author{
Erik C. Zobrist, Bruce C. Coull \\ Belle W. Baruch Institute of Marine Biology and Coastal Research and Department of Biological Sciences, University of \\ South Carolina, Columbia, South Carolina 29208, USA
}

\begin{abstract}
The meiofaunal bottleneck hypothesis states that permanent meiofauna (e.g. nematodes, copepods, foraminifera) negatively affect macrofaunal larval settlement and juvenile survivorship. Field studies suggest enhanced meiofaunal densities decrease recruitment of some macrofauna but do not identify whether this is a settlement or post-settlement process. Our experiments specifically examined the settlement response of the spionid polychaete Streblospio benedicti Webster and the venerid bivalve Mercenaria mercenaria (L.) to functionally different meiofaunal taxa (burrower, epibenthic, sediment sweeper). ANOVA revealed no significant effect of any meiofaunal taxon on macrofaunal settlement. Further experiments on emigration of recently-settled $(<24 \mathrm{~h}$ old) juvenile $S$. benedicti and $M$. mercenaria showed no difference in burial times (time from initial juvenile contact with the sediment surface until complete burial below the sediment surface) between meiofaunal treatments and control sediments. Our data suggest that if the meiofaunal bottleneck exists, it is not a settlement phenomenon nor does it cause emigration of these recently-settled macrofauna.
\end{abstract}

\section{INTRODUCTION}

Competition has presumably exerted considerable influence in the evolutionary history of natural communities, but has been generally difficult to document in nature (Miller 1967), especially in soft-bottom benthic communities (Peterson 1979, 1991, Wilson 1991). Neill (1975) described a competitive bottleneck for microcrustaceans where age- or size-specific competition at one stage of an organism's life history ramified throughout subsequent stages. The possibility of a meiofaunal bottleneck (Bell \& Coull 1980) has been proposed, whereby permanent meiofauna negatively af fect settling macrofauna larvae and recently-settled juveniles.

When macrofauna larvae settle into the benthos, they can be described as meiofauna-sized macrofauna or 'temporary meiofauna' (sensu McIntyre 1964). This term simply defines the stage during which they are physically the same size $<500 \mu \mathrm{m}$; Shroeder \& Her-

\footnotetext{
- Contribution No. 958 from the Belle W. Baruch Institute for Marine Biology and Coastal Research
}

mans 1975, Sastry 1979) as the permanent meiofauna that is frequently dominated by nematodes, copepods and foraminifera (Hicks \& Coull 1983). Warwick (1984) found that body size-frequency curves of recentlysettled polychaetes and echinoderms overlapped with those of the meiofauna. Long-term field data from North Inlet, South Carolina, USA, on polychaete and bivalve abundances show distinct time lags in peak abundance between meiobenthic and macrobenthic stages, with apparent large losses in between (Stancyk \& Feller 1986, Feller et al. 1992), suggesting important mortality events between these life-history stages.

Several observations suggest that juvenile macrofaunameiofauna interactions may be important: (1) juvenile macrofauna appear in the meiofaunal community during periods of seasonal increases in permanent meiofauna (Yingst \& Rhoads 1978, Bell 1979), (2) the majority of juvenile macrofauna utilize the upper $1 \mathrm{~cm}$ of sediment where meiofauna are also most abundant (Bell 1979, Coull \& Bell 1979, Yingst 1978) and (3) juvenile macrofauna and meiofauna both feed on diatoms and bacteria (Fauchald \& Jumars 1979, Montagna 1984). 
Recruitment success of some macrofauna is reduced in treatments with enhanced meiofaunal densities in field manipulations of 1 to $4 \mathrm{wk}$ duration (Bell \& Coull 1980, Watzin 1983, 1986). One aspect of this reduction may be predation; predaceous turbellarians ingest polychaete and bivalve juveniles (Thorson 1966, Watzin 1985) in the laboratory. What is less clear is the effect of other, more numerically dominant, meiobenthic taxa (i.e. nematodes and copepods) on larval recruitment, especially in muddy substrates where predaceous turbellarians are not abundant. None of these field experiments could identify the exact nature of the interaction or distinguish between settlement and post-settlement processes that exert significant effects on subsequent population structure of macrofauna (Luckenbach 1984, Connell 1985, Peterson 1986, Woodin 1986, 1991).

Our goal was to distinguish settlement from postsettlement events. Experiments specifically examined (1) larval settlement patterns and (2) recently-settled juvenile emigration of 2 common macrobenthic species in response to functionally different meiofauna.

\section{METHODS}

Meiofaunal treatments represented 3 functional groups: (1) burrowers - harpacticoid copepods Nannopus palustris Brady, Stenhelia (D.) bifidia Coull, and 'bulk' nematodes, (2) epibenthic flitters - the harpacticoid copepod Microarthridion littorale (Poppe) which actively moves across the sediment surface and (3) surface sediment sweepers - the foraminiferan Ammonia beccarri (L.) which extends its reticulopodia across the sediment surface to feed. Macrofaunal species included the planktotrophic morph of the spionid polychaete Streblospio benedicti Webster (Levin 1984) and the venerid bivalve Mercenaria mercenaria (L.) which also has planktotrophic development (Carriker 1961). All co-occur and are common meiobenthic (Coull 1985, Coull \& Dudley 1985) and macrobenthic (Holland 1974, Service \& Feller 1992) species in southeastern USA estuaries.

Meiofauna and Streblospio benedicti were collected

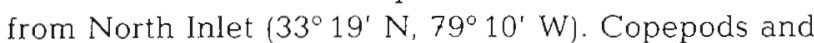
nematodes were collected fresh for each experiment, while cultures of Ammonia beccarri and S. benedicti were maintained in the laboratory. The 'bulk' nematode treatment was a composite of numerous species extracted from field sediments (Couch 1988). Mercenaria mercenaria pediveligers were hatchery reared. (see 'Acknowledgements'). All cultures and macrofaunal larvae were fed the alga T-Isochrysis galbana (Chrysophyceae, Chrysophyta). Each meiofaunal and macrofaunal species was paired in single-species interaction experiments.
Settlement experiments were performed in glass chambers $(9 \times 9 \times 6 \mathrm{~cm})$ holding $500 \mathrm{ml}$ synthetic seawater ( $28 \mathrm{ppt}$ ). The chamber base (Fig 1A) was a tissue culture plate cut into a $4 \times 4$ array of wells. These 16 wells $\left(1.5 \mathrm{~cm}\right.$ deep, surface area $\left.2 \mathrm{~cm}^{2}\right)$ served as patch sites for controls (no meiofauna) and treatments arranged in a checkerboard pattern. Each well contained $1 \mathrm{ml}$ of sterile mud (Chandler 1986), creating a sediment patch $0.5 \mathrm{~cm}$ deep; sediment patches occupied $40 \%$ of the chamber bottom. Any stray sediment particles on the chamber bottom were aspirated away. Plastic tubes were inserted into each well, protruding above the water level. Meiofauna were pipetted into alternating tubes and allowed to establish themselves in well sediments for $24 \mathrm{~h}$, after which the tubes were removed. Meiofaunal treatment densities per well reflected high intertidal field densities: Nannopus palustris, 25; Stenhelia bifidia, 20; Microarthridion littorale, 25; Ammonia beccarri, 70; nematodes, ca 250. Nematode treatments were established from a meiofaunal sample splitter (Elmgren 1973) to yield approximate densities of 250 well $^{-1}(\bar{x}=263.3, \mathrm{SD}=16.4, \mathrm{n}=10)$ while other taxa were allotted individually. Streblospio benedicti larvae (200 chamber $^{-1}$ ) in the terminal 11-12 setiger planktonic stage or Mercenaria mercenaria late pediveligers (500 chamber $^{-1}$ ) were added to the water contained within the chamber and allowed to settle for $24 \mathrm{~h}$. At termination the plastic tubes were reinserted and the wells were inspected for meiofauna and metamorphosed juveniles. All experiments followed this procedure except for the $M$. littorale treatment. This epibenthic copepod is errant; to maintain the treatment densities, plastic tubes were left in each well (treatment and control) throughout the duration of the experiment. Larvae were placed into each tube ( $S$. benedicti: 10 well $^{-1} ; M$. mercenaria, 25 well $^{-1}$ ) and restricted by the tube to sediment patches rather than dispersed throughout the chamber. In all experiments, meta-
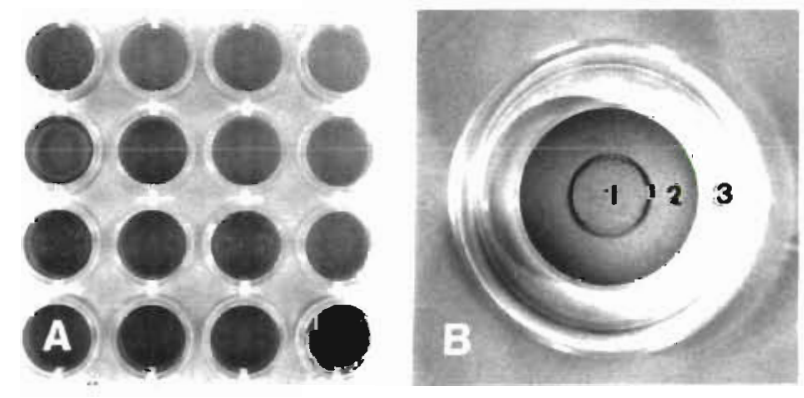

Fig. 1 (a) Chamber for settlement experiments showing $4 \times 4$ array of alternating treatment and control sediment patches on the chamber bottom $(9 \times 9 \mathrm{~cm})$. Note that there is no sediment between wells (well surface area $2 \mathrm{~cm}^{2}$ ). (b) Nested dishes for emigration experiment. (1) Inner meiofaunal plug: (2) doughnut of control sediment; (3) outer dish. Outer dish diameter $6 \mathrm{~cm}$ 
morphosed juveniles of $S$. benedicti were determined by tube building activity and lack of swimming setae $M$. mercenaria were considered juveniles if they no longer possessed a velum. Two settlement chambers were run concurrently during each experiment. For each meiofaunal taxon ( 3 burrowers, 1 epibenthic flitter, 1 sediment sweeper), the experiments were temporally replicated 3 times for $S$. benedicti and twice for $M$. mercenaria. Since many meiofauna are positively phototactic, all experiments were conducted in a dark environmental chamber at $25^{\circ} \mathrm{C}$

Emigration experiments were conducted within 3 nested plastic dishes (Fig. 1B). Sterile sediment was added to the inner 2 dishes. The innermost dish was slightly shallower than the middle dish, so there was a 3 to $4 \mathrm{~mm}$ continuous sediment layer across the 2 dishes. Synthetic seawater ( $28 \mathrm{ppt}$ ) was added to the taller outer dish $(6 \mathrm{~cm}$ diameter) until the sediment of the inner rings was covered to a depth of about $0.5 \mathrm{~cm}$. A plastic tube was inserted snugly into the innermost dish and meiofauna were added and allowed to establish themselves in the dark. The tube was removed after $12 \mathrm{~h}$, yielding an innermost meiofaunal plug surrounded by a doughnut of control sediment. One recently-settled juvenile ( $<24$ h old) Streblospio benedicti or Mercenaria mercenaria was added to the surface of the meiofaunal plug or the control sediment and observed under a dissecting microscope. Time from initial juvenile contact with the sediment surface until complete burial below the sediment surface was recorded. In total, 6 juveniles were added to treatments or controls in each of 4 dishes, replicated twice in time for a total of 48 trials per meiofaunal treatment.

Raw Mercenaria mercenaria and $\log (x+1)$-transformed Streblospio benedicti settlement densities were analyzed by 3-way ANOVA (treatment and chamber, fixed; time, random). A reduced ANOVA was performed on pooled data when factors and interactions were not significant. To maintain an experimentwise error rate of $\alpha=0.05$, each ANOVA was evaluated at an $\alpha^{\prime}=$ 0.025 (Sokal \& Rolf 1981). Raw emigration times were analyzed by 3-way ANOVA (treatment and dish, fixed; time, random; $\alpha=0.05$ ). All ANOVAs were performed by SAS Institute (1985) statistical analysis programs. Sensitivity of settlement experiments was determined through post hoc power $(1-\beta)$ analysis of pooled data following the methods outlined in Sokal \& Rohlf (1981). When calculating power, the null hypothesis is tested against a specific, alternative hypothesis. The null hypothesis $\left(H_{0}\right)$ was no difference between treatment and control means. Two alternative hypotheses were a $35 \%\left(H_{\mathrm{a}}\right)$ and $50 \%\left(\mathrm{H}_{\mathrm{b}}\right)$ reduction in treatment from control means.

To observe modification of sediment structure by meiofauna, small observation chambers were constructed out of clear, thin plastic slides $(6 \times 3 \times 1 \mathrm{~cm})$ with a $3 \times 2 \mathrm{~cm}$ viewing trough cut from the long axis of the slide. Glass cover slips were mounted with silicone glue on both sides of the plastic slide, producing an observation chamber ca $2 \mathrm{~cm}$ thick. After $0.5 \mathrm{ml}$ of sterile mud was gently placed into the chamber with artificial seawater, meiofauna were added at densities equal to settlement experiments. Meiofaunal effects on sediment structure could be assessed qualitatively after $12 \mathrm{~h}$.

\section{RESULTS}

Meiofauna treatments maintained fidelity throughout the experiment. Examination of all 16 sediment patches within a chamber revealed no significant movement from treatment to control patches. Streblospio benedicti settlement showed a consistent response across all 5 meiofaunal treatments (Fig. 2). ANOVA revealed no treatment or chamber effect on settlement for any of the 5 meiofaunal taxa, and all interactions were non-significant. Between 18 and $94 \%$ of $S$. benedicti larvae settled per chamber. This variation in

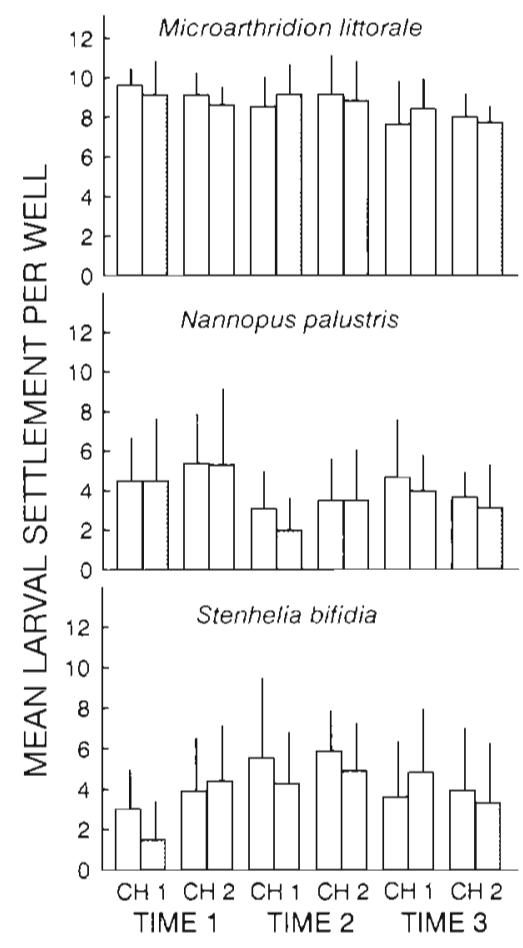

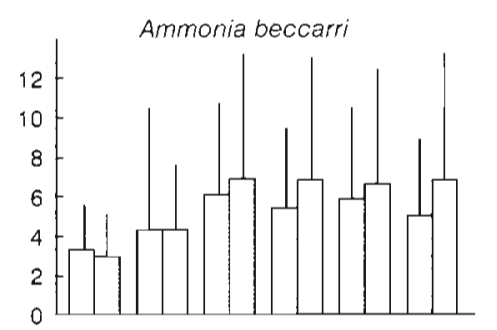

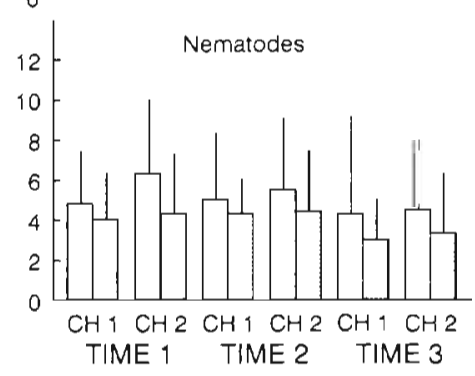

\begin{tabular}{|l|}
$\square$ CONTROL \\
$\square$ TREATMENT \\
\hline
\end{tabular}

Fig. 2. Streblospio benedicti. Mean larval settlement per well + 1 SD in meiofaunal treatments; values untransformed 

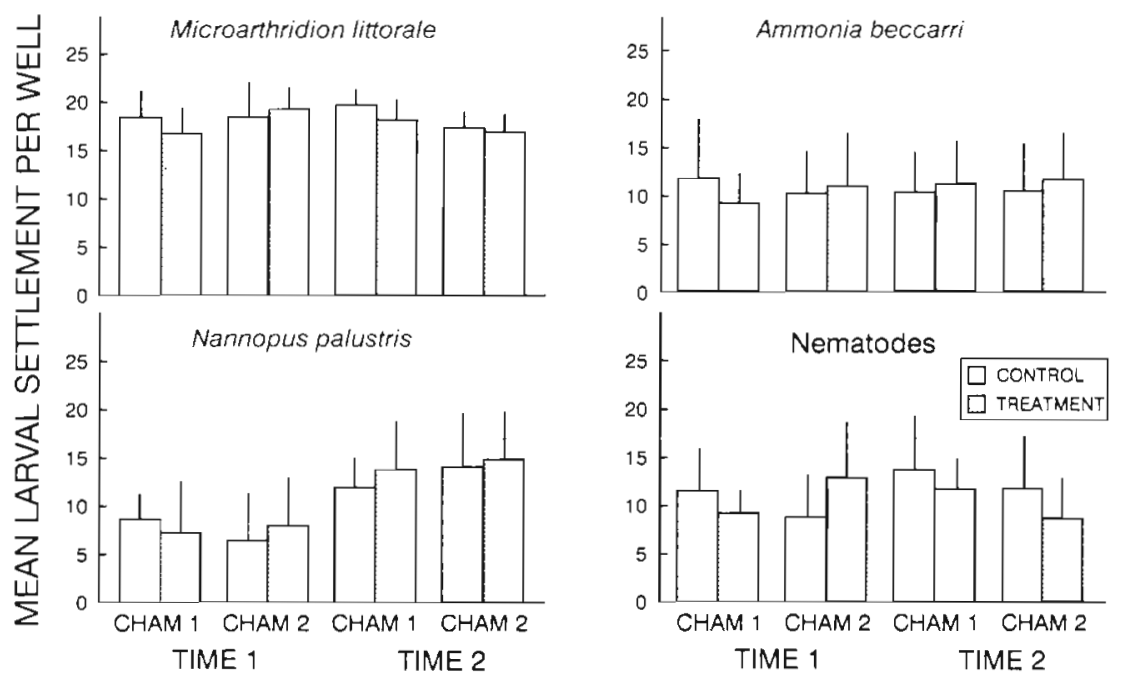

Fig. 3. Mercenaria mercenaria. Mean larval settlement per well $+1 \mathrm{SD}$ in meiofaunal treatments; values untransformed

settlement produced a significant time effect within the meiofaunal treatments Nannopus palustris $\left(F_{2,90}=\right.$ $4.31, \mathrm{p}<0.05)$, Stenhelia bifidia $\left(F_{2,90}=5.13, \mathrm{p}<0.01\right)$ and Ammonia beccarri $\left(F_{2.90}=4.83, p<0.05\right)$. Settlement response of Mercenaria mercenaria was also consistent across the 4 meiofauna treatments tested (Fig. 3). Treatment, chamber, time and all interactions were non-significant. Larval settlement per experiment varied from 25 to $76 \%$ but only produced a significant time effect within the $N$. palustris $\left(F_{1,60}=\right.$ 25.70, p<0.001) treatment. Nearly all $S$. benedicti and M. mercenaria not found in chamber sediments were unmetamorphosed larvae in the water column; fewer than $5 \%$ settled on the plastic bottom between wells. Post hoc power analysis on all settlement data revealed that a $35 \%$ reduction in settlement $\left(H_{\mathrm{a}}\right)$ could be detected with a power of at least 0.53 and a $50 \%$ reduction in settlement $\left(H_{\mathrm{b}}\right)$ could be detected with a power of at least 0.79 for every treatment (Table 1).
Streblospio benedicti and Mercenaria mercenaria settlement was consistently greater in the Microarthriodion littorale treatment (Figs. 2 \& 3). We reasoned that since larvae were tube-restricted to $100 \%$ sediment patches in contrast to the other treatments without tubes where only $40 \%$ of the chamber bottom was sediment patches (see 'Methods'), this manipulation accounted for the higher settlement. To test this idea we performed additional settlement experiments with tube-restricted $S$. benedicti larvae and Ammonia beccarri as the treatment. Settlement rates of tube-restricted larvae per chamber were higher (78 to $89 \%$ ) than in the non-tube $A$. bec carri treatment (25 to $52 \%$ ) and comparable to the $M$. littorale treatments ( 88 to $94 \%$ ).

Emigration experiments with recently-settled juveniles ( $<24 \mathrm{~h}$ old) of Streblospio benedicti and Mercenaria mercenaria indicated no differential response to meiofauna. Although juvenile $M$. mercenaria required more time to bury than $S$. benedicti juveniles (Table 2), all main effects (treatment, dish, time) and interactions were non-significant for burrowing times of both macrofauna species.

Meiofaunal activity generated dramatic and diverse modifications of surficial sediments in our observation chambers. The epibenthic copepod Microarthridion littorale (Fig. 4A $\mathrm{A}^{1}, \mathrm{~A}^{2}$ ) occasionally burrowed but mostly fluffed surface sediments; Nannopus palustris (Fig. $4 \mathrm{~B}^{1}, \mathrm{~B}^{2}$ ) burrowed extensively into deeper sediments. Nematodes (Fig. $4 \mathrm{C}^{1}, \mathrm{C}^{2}$ ) wove a fine network of burrows that created a spongy surface of noticeably reduced particle cohesion, whereas the foraminiferan

Table 1 Post hoc power analysis on transformed data $[\log (\mathrm{x}+1)]$ of Streblospio benedicti and of untransformed Mercenaria mercenaria settlement for each meiofaunal treatment. Alternative hypotheses tested were a $35 \%\left(H_{0}\right)$ and $50 \%\left(H_{\mathrm{b}}\right)$ reduction in mean settlement in treatments from controls. Data were pooled among time replicates not significantly different (Bonferroni multiple comparisons, $\alpha=0.05$ )

\begin{tabular}{|c|c|c|c|c|c|c|c|c|}
\hline \multirow[t]{2}{*}{ Treatment } & \multicolumn{4}{|c|}{ Streblospio benedicti } & \multicolumn{4}{|c|}{ Mercenaria mercenaria } \\
\hline & $35 \%$ & $50 \%$ & $\mathrm{n}$ & Pooled replicates & $35 \%$ & $50 \%$ & $\mathrm{n}$ & Pooled replicates \\
\hline Microarthridion littorale & ca 1.00 & ca 1.00 & 48 & $1+2+3$ & ca 1.00 & ca 1.00 & 32 & $1+2$ \\
\hline Nematodes & 0.79 & 0.99 & 48 & $1+2+3$ & 0.97 & 0.99 & 32 & $1+2$ \\
\hline Ammonia beccarri & 0.65 & 0.93 & 32 & $2+3$ & 0.94 & 0.99 & 32 & $1+2$ \\
\hline Nannopus palustris & $\begin{array}{l}0.82 \\
0.80\end{array}$ & $\begin{array}{l}0.99 \\
0.99\end{array}$ & $\begin{array}{l}32 \\
32\end{array}$ & $\begin{array}{l}1+3 \\
2+3\end{array}$ & $\begin{array}{l}0.53 \\
0.90\end{array}$ & $\begin{array}{l}0.79 \\
0.99\end{array}$ & $\begin{array}{l}16 \\
16\end{array}$ & $\begin{array}{l}1 \\
2\end{array}$ \\
\hline Stenhelia bifidıa & $\begin{array}{l}0.56 \\
0.67\end{array}$ & $\begin{array}{l}0.88 \\
0.94\end{array}$ & $\begin{array}{l}32 \\
32\end{array}$ & $\begin{array}{l}1+3 \\
2+3\end{array}$ & $\begin{array}{l}- \\
-\end{array}$ & $\begin{array}{l}- \\
-\end{array}$ & $\begin{array}{l}- \\
-\end{array}$ & $\begin{array}{l}- \\
-\end{array}$ \\
\hline
\end{tabular}


Table 2. Burial times (s) of <24 h old post-settlement juveniles of Streblospio benedicti and Mercenaria mercenaria to meiofaunal treatments. Data are pooled within each treatment $(n=24)$

\begin{tabular}{|c|c|c|c|c|}
\hline \multirow[t]{2}{*}{ Treatment } & \multicolumn{2}{|c|}{ Streblospio benedicti } & \multicolumn{2}{|c|}{ Mercenaria mercenaria } \\
\hline & $\bar{x} \pm \mathrm{SD}$ & Range & $\vec{x} \pm \mathrm{SD}$ & Range \\
\hline Nannopus palustris & $20.5 \pm 8.0$ & $10-38$ & $93.8 \pm 56.3$ & $16-212$ \\
\hline Control & $15.8 \pm 5.8$ & $8-26$ & $94.0 \pm 48.7$ & $8-223$ \\
\hline Stenhelia bifidia & $21.6 \pm 6.9$ & $11-37$ & - & - \\
\hline Control & $22.3 \pm 6.7$ & $14-35$ & - & - \\
\hline Microarthridion littorale & $20.5 \pm 11.0$ & $3-42$ & $56.5 \pm 38.4$ & $14-167$ \\
\hline Control & $22.3 \pm 7.5$ & $9-36$ & $75.7 \pm 53.9$ & $9-201$ \\
\hline Ammonia beccarri & $18.5 \pm 8.5$ & $7-41$ & $82.7 \pm 52.1$ & $17-267$ \\
\hline Control & $23.8 \pm 6.1$ & $8-38$ & $70.4 \pm 48.9$ & $12-243$ \\
\hline Nematodes & $27.8 \pm 9.9$ & $12-49$ & $91.3 \pm 62.2$ & $8-296$ \\
\hline Control & $20.7 \pm 8.8$ & $6-37$ & $73.1 \pm 55.3$ & $19-215$ \\
\hline
\end{tabular}

Ammonia beccarri (Fig. 4D ${ }^{1}, D^{2}$ ) granulated surface sediments and noticeably increased particle cohesion (also see Chandler 1989). The meiofaunal taxa in our experiments clearly modified sediment structure relative to control sediments (Fig. $4 E^{1}, E^{2}$ ).

\section{DISCUSSION}

Competitive interactions are usually divided into 2 modes: interference and exploitation (Miller 1967). Considering the diverse nature of meiofauna in sedimentary habitats, it is puzzling that some form of interaction was not detected. Permanent meiofauna consist of at least 22 metazoan and several protoctistan phyla, possess many modes of existence (e.g. burrowing, epibenthic, tube building), reach very high densities (Higgins \& Thiel 1988), and are known to alter surface sediment characteristics significantly (Cullen 1973, Yingst \& Rhoads 1978, Chandler 1989). We chose meiofaunal treatments to represent functional groups that we thought would aid in identifying means of interactions. Perhaps burrowing meiofauna (nematodes and copepods Nannopus palustris and Stenhelia bifidia) do not affect macrofaunal settlement since they are not concentrated at the immediate sediment surface where larvae settle. Vertical distribution studies indicate $N$ palustris reaches highest densities at 2 to $4 \mathrm{~mm}$ below the surface and $S$. bifidia at 5 to $6 \mathrm{~mm}$, while nematode numbers increase below $3 \mathrm{~mm}$ (Coull et al. 1989). Additionally, the 2 meiofaunal taxa active at the sediment surface did not affect larval settlement. The epibenthic copepod Microarthridion littorale flits actively across sediments (pers. obs.). The foraminiferan Ammonia beccarri dramatically increases median grain diameter (Chandler 1989) and consumes large amounts of sediment bacteria and microphytobenthos (Muller 1975, Lee et al. 1972) through its feeding activities. Settling macrobenthic larvae and recently-settled juveniles are capable of distinguishing sediment patches over a scale of centimeters (Butman et al. 1988, Woodin \& Marinelli 1991, Chandler \& Scott 1991). Despite meiofaunal activities that seemingly might interfere with macrofaunal larval settlement or force juvenile emigration, neither settlement nor emigration of Streblospio benedicti or Mercenaria mercenaria was affected.

A significant time effect was detected (ANOVA) in 3 meiofaunal treatments in experiments with Streblospio benedicti and one with Mercenaria mercenaria. Several spawns of both $S$. benedicti and Mercenaria mercenaria provided larvae for experiments. Even though all larvae were reared in an identical manner (e.g. temperature, light, food), variation in time to reaching larval competency could be observed (Hadfield 1984). Despite such a 'larval cohort' difference, $S$. benedicti and $M$. mercenaria settlement response was consistent across all meiofaunal treatments.

In light of such non-significant treatment effects, post hoc power analysis is appropriate to evaluate the sensitivity of tests of the null hypothesis (Andrew \& Mapstone 1987). When calculating power $(1-\beta)$ the null hypothesis must be tested against a specific alternative hypothesis. Our $35 \%\left(H_{a}\right)$ and $50 \%\left(H_{b}\right)$ reductions in mean larval settlement in treatments from controls were calculated from raw data. Power anályses for Mercenaria mercenaria were calculated on raw data; power analyses for Streblospio benedicti were calculated on $\log (x+1)$-transformed data resulting in detectable differences far smaller than 35 and $50 \%$ (ca 20 and $31 \%$ respectively). Power was routinely above 0.80 (Table 1), the commonly accepted power level in ecological research (Underwood 1981). Our experimental design was strong enough to detect a $35 \%$ reduction in settlement, and thus the non- 

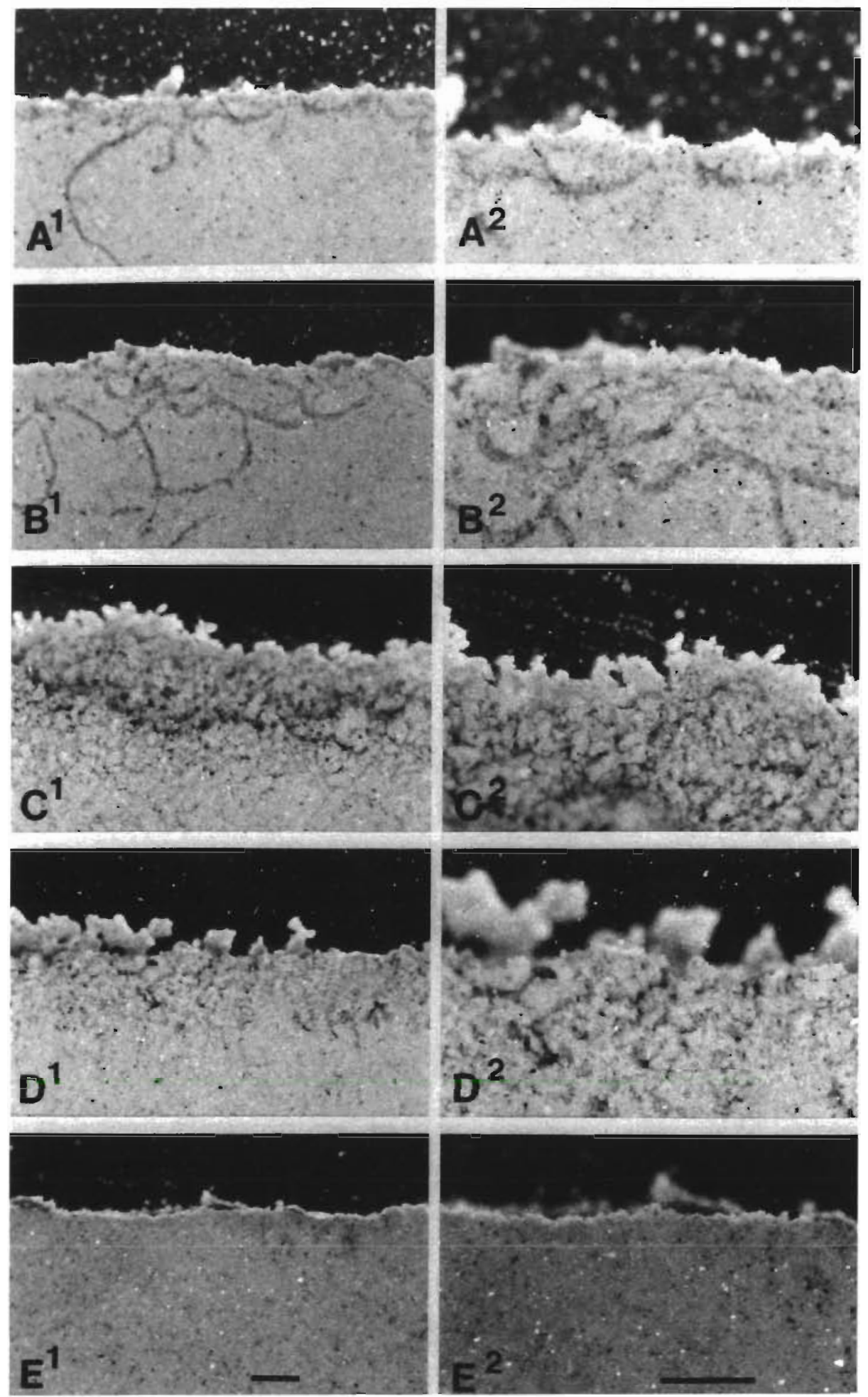

Fig. 4 Cross-sectional view $\left[\left(1^{1}\right) \times 6.5 ;\left({ }^{2}\right) \times 13\right]$ of sediment modification by meiofauna: (A) Microarthridion littorale; (B) Nannopus palustris; (C) Nematodes; (D) Ammonia beccarri. (E) Control. Scale bars $=1 \mathrm{~mm}$

significant ANOVAs result from genuinely small differences between controls and treatments. This reduction $(35 \%)$ may still appear large, but within the context of our experiments is very ecologically relevant. Larval settlement can be highly variable and can differ by an order of magnitude over a scale of centimeters (Butman et al. 1988). Other processes exerting significant interactions at this spatial scale $(\mathrm{cm})$ in soft-bottom habitats include interference among macrofauna (Holme 1950, Roe 1975, Levin 
1982) and ammensalism and facilitation among meiofauna (Chandler \& Fleeger 1987, Chandler 1989).

Power analysis is a fundamental statistical tool in ecological research (Toft \& Shea 1983) but only recently has been performed to gain inference on negative results (e.g. McCann \& Levin 1989, Hall et al. 1990, Service et al. 1992). Negative results such as reported in this paper are just as insightful as positive results when subjected to power analysis. It is quite possible that understanding of certain ecological processes may be tainted as a result of 'unsuccessful' experiments going unpublished (Peterson 1979).

The meiofaunal bottleneck theory remains equivocal. Positive correlations of meiofauna and macrofauna in the field seemingly contradict negative interactions (Armonies \& Hellig-Armonies 1987). In contrast, field experiments suggesting competition between oligochaetes and the ampharetid polychaete Hobsonia florida (Gallagher et al. 1990) add credence to a possible bottleneck; however, oligochaetes are usually not a major component of meiofaunal communities and many species are considered macrofaunal (Erséus 1988).

Data presented here indicate that the bottleneck is not a settlement phenomenon for the 2 macrofaunal species we tested when interacting with specific meiofaunal taxa. We chose Streblospio benedicti and Mercenaria mercenaria because they are common macrobenthic species. A significant reduction in settlement of a common species would suggest a greater universality of the effect; however, they may be so common because they are not highly discriminating during settlement (but see Chandler \& Scott 1991). The results reported here should be judged within the context of the experimental design. We recognize that macrofaunal settlement into a mixed meiofaunal assemblage may be affected differently via diffuse competition. Additionally, our results might differ under flowing water (Butman et al. 1988). Nevertheless, our experiments indicate that numerically dominant meiofauna such as nematodes and copepods do not significantly affect $S$. benedicti or $M$. mercenaria settlement or emigration. The question remains whether the bottleneck exists as a post-settlement process. What is needed are growth and survivorship data on macrofauna in the presence of major meiofauna taxa. They would answer whether the bottleneck occurs as a post-settlement interaction during the time macrofauna spend as temporary meiofauna

Acknowledgements. We thank M. Castagna (Virginia Institute of Marine Science, Wachapreague, VA.) and N. Hadley (South Carolina Wildlife and Marine Resources Department, Charleston, SC) for generously providing healthy Mercenaria mercenaria pediveligers. We also thank G. T. Chandler, P. A. Jumars, S. E. Stancyk, R. M. Warwick and S. A. Woodin for critical discussions and reviews of the manuscript. R. Woods assisted in field collections. This research was supported by a National Science Foundation Grant, OCE 89-16255 Biological Oceanography Section, to B.C.C. and is based on a dissertation by E.C.Z. to be submitted to the graduate school at the University of South Carolina for partial fulfillment of the requirements for a Ph.D. degree in Biological Sciences

\section{LITERATURE CITED}

Armonies, W., Hellwig-Armonies, M. (1987). Synoptic patterns of meiofaunal and macrofaunal abundances and specific composition in littoral sediments. Helgoländer Meeresunters. 41: 83-111

Andrew, N. L., Mapstone, B. D. (1987). Sampling and the description of spatial pattern in marine ecology. Oceanogr mar. Biol. A. Rev. 25: 39-90

Bell, S. S. (1979). Short- and long-term variation in a high marsh meiofaunal community. Estuar. coast. mar. Sci. 9: 331-350

Bell, S. S., Coull, B. C. (1980). Experimental evidence for a model of juvenile macrofauna-meiofauna interactions. In: Tenore, K., Coull, B. C. (eds.) Marine benthic dynamics. Univ. South Carolina Press, Columbia, p. 179-188

Butman, C. A., Grassle, J. P., Webb, C. M. (1988). Substrate choices made by marine larvae settling in still water and in a flume flow. Nature 333: 771-773

Carriker, M. R. (1961). Interrelation of functional morphology, behavior, and autecology in early stages of the bivalve Mercenaria mercenaria. J. Elisha Mitchell scient. Soc. 77 : $168-241$

Chandler, G. T (1986). High density culture of meiobenthic harpacticoid copepods within a muddy sediment substrate. Can. J. Fish Aquat. Sci. 43: 53-59

Chandler, G. T. (1989). Foraminifera may structure meiobenthic communities. Oecologia 81: 354-360

Chandler, G. T., Fleeger, J. W. (1987). Facilitative and inhibitory interactions among estuarine meiobenthic harpacticoid copepods. Ecology 42: 1906-1919

Chandler, G. T., Scott, G. 1. (1991). Effects of sediment-bound endosulfan on survival, reproduction and larval settlement of meiobenthic polychaetes and copepods. Environ. Toxicol. Chem. 10: 375-382

Connell, J. H. (1985). The consequence of variation in settlement vs. post-settlement mortality in rocky intertidal communities. J. exp. mar. Ecol. Biol. 93: 11-45

Couch, C. A. (1988). A procedure for extracting large numbers of debris-free, living nematodes from muddy marine sediments. Trans. Am. microsc. Soc. 107: 96-100

Coull, B. C. (1985). Long-term variability of estuarine meiobenthos: an 11 year study. Mar. Ecol. Prog. Ser. 24: 205-118

Coull, B. C., Bell, S. S. (1979). Perspectives of marine meiofaunal ecology. In: Livingston, R. J. (ed.) Ecological processes in coastal and marine ecosystems. Plenum Press, New York, p. 189-216

Coull, B. C., Dudley, B. W. (1985). Dynamics of meiobenthic copepod populations: a long-term study (1973-1983). Mar Ecol. Prog. Ser. 24: 219-229

Coull, B. C., Palmer, M. A., Myers, P. E. (1989). Controls on the vertical distribution of meiobenthos in mud: field and flume studies with juvenile fish. Mar. Ecol. Prog. Ser. 55: 133-139

Cullen, D. J. (1973). Bioturbation of superficial marine sediments by interstitial meiobenthos. Nature 242: 323-234

Elmgren, R. (1973). Methods of sampling sublittoral soft bottom meiofauna. Oikos suppl. 15: 112-120

Erséus, C. (1988). Oligochaeta. In: Higgins, R. P., Thiel, H. (eds.) Introduction to the study of meiofauna. Smithsonian 
Institution Press, Washington D.C., p. 349-354

Fauchald, K., Jumars, P. A. (1979). The diet of worms: a study of polychaete feeding guilds. Oceanogr. A. Rev. mar. Biol. 17: $193-284$

Feller, R. J., Stancyk, S. E., Coull, B. C., Edwards, D. G. (1992). Recruitment of polychaetes and bivalves: long-term assessment of predictability in a soft-sediment habitat. Mar. Ecol. Prog. Ser. 87: 227-238

Gallagher, E. D.. Gardner, G. B., Jumars, P. A. (1990). Competition among the pioneers in a seasonal soft-bottom benthic succession: field experiments and analysis of the Gilpin-Ayala competition model. Oecologia 83: 427-442

Hadfield, M. G. (1984). Settlement requirements of molluscan larvae: new data on chemical and genetic roles. Aquaculture 39: 283-298

Hall, S. J., Raffaelli, D., Turrell, W. R. (1990). Predator-caging experiments in marine systems: a reexamination of their value. Am. Nat. 136: 657-672

Hicks, G. R. F., Coull, B. C. (1983). The ecology of marine meiobenthic harpacticoid copepods. Oceanogr. mar. Biol. A. Rev. 21: 67-175

Higgins, R. P., Thiel, H. (eds.) (1988). Introduction to the study of meiofauna. Smithsonian Institution Press, Washington D.C.

Holme, N. A. (1950). Population-dispersion in Tellina tenuis da Costa. J. mar. biol. Ass. U.K. 29: 267-280

Holland, A. F. (1974). A study of the intertidal macrofaunal communities inhabiting sand and mud bars of the North Atlantic area near Georgetown, SC, USA. Ph.D. dissertation, Univ. of South Carolina, Columbia

Lee, J. J., Stone, R. J., McEnergy, M., Muller, W. A. (1972). Physiological perspectives on the ecology of Foraminifera in a Long Island salt marsh. Proc. Shellfish Culture Conference, Reg. Mar. Res. Council, Nassau-Suffolk Regional Planning Board, p. 11-32

Levin, L. A. (1982). Interference interactions among tubedwelling polychaetes in a dense infaunal assemblage. J. exp. mar. Biol. Ecol. 65: 107-119

Levin, L. A. (1984). Multiple patterns of development in Streblospio benedicti Webster (Spionidae) from three coasts of North America. Biol. Bull. 166: 494-508

Luckenbach, M. W. (1984). Settlement and early postsettlement survival in the recruitment of Mulinia lateralis (Bivalvia). Mar. Ecol. Prog. Ser. 17: 245-250

McCann, L. D., Levin, L. A. (1989). Oligochaete influence on settlement, growth and reproduction in a surface-deposit feeding polychaete. J. exp. mar. Biol. Ecol. 131: 233-253

McIntyre, A. D. (1964). Meiobenthos of sublittoral muds. J. mar. biol. Ass. U.K. 44:665-674

Miller, R. S. (1967). Pattern and process in competition. In: Cragg, J B. (ed.) Advances in ecological research. Academic Press, London, p. 1-74

Montagna, P. A. (1984). In situ measurement of meiobenthic grazing rates on sediment bacteria and edaphic diatoms. Mar. Ecol. Prog. Ser. 18: 119-130

Muller, W. A. (1975). Competition for food and other nicherelated studies of three species of salt-marsh Foraminifera. Mar. Biol. 31: 339-351

Neill, W. E. (1975). Experimental studies of microcrustacean competition, community composition and efficiency of resource utilization. Ecology 56: 809-826

Peterson, C. H. (1979). Predation, competitive exclusion, and diversity in the soft-sediment benthic communities of estuanes and lagoons. In: Livingston, R. J. (ed.) Ecological. processes in coastal and marine systems. Plenum, New York, p. 233-264

Peterson, C. H. (1986). Enhancement of Mercenaria merce- naria densities in seagrass beds: is pattern fixed during settlement season or altered by subsequent differential survival? Limnol. Oceanogr. 31: 200-205

Peterson, C. H. (1991). Intertidal zonation of marine invertebrates in sand and mud. Am. Sci. 79: 236-249

Roe, P. (1975). Aspects of life history and of territorial behavior in young individuals of Platynereis bicanaliculata and Nereis vexillosa (Polychaeta, Annelida). Pacif. Sci. 29: $341-348$

SAS Institute (1985). SAS user's guide: statistics. Version 5 edn. SAS Institute, Cary, NC

Sastry, A. N. (1979). Pelecypoda (excluding Ostreidae). In: Giese, A. C., Pearse, J. S. (eds.) Reproduction of marine invertebrates, Vol. IV, Molluscs: Pelecypoda and lesser classes. Academic Press, New York, p. 113-292

Schroeder, P. C., Hermans, C. O. (1975). Annelida: Polychaeta. In: Giese, A. C., Pearse, J. S. (eds.) Reproduction of marine invertebrates, Vol. III, Annelids and echiurans. Academic Press, New York, p. 1-213

Service, S. K., Feller, R. J. (1992). Long-term trends in subtidal macrobenthos in North Inlet, South Carolina. Hydrobiologia 231. 13-40

Service, S. K., Feller, R. J., Coull, B. C., Woods, R. (1992). Predation effect of three fish species and a shrimp on macrobenthos and meiobenthos in microcosms. Estuar coast. Shelf Sci. 34: 277-293

Sokal, R. R., Rolf, F. J. (1981). Biometry. Freeman and Co., San Francisco

Stancyk, S. E., Feller, R. J (1986). Transport of non-decapod larvae in estuaries: an overview. Bull. mar. Sci. 39: 257-268

Thorson, G. (1966). Some factors influencing the recruitment and establishment of marine benthic communities. Neth. J. Sea Res. 3: $267-293$

Toft, C. A., Shea, P. J. (1983). Detecting community-wide patterns: estimating power strengthens statistical inference. Am. Nat. 122: 618-625

Underwood, A. J. (1981). Techniques of analysis of variance in experimental marine biology and ecology. Oceanogr. Mar. Biol. A. Rev. 19: 513-605

Warwick, R. M. (1984). Species size distributions in marine benthic communities. Decologia 64: 32-41

Watzin, M. C. (1983). The effects of meiofauna on settling macrofauna: meiofauna may structure macrofaunal communities. Oecologia 59: 163-166

Watzin, M. C. (1985). Interaction among temporary and permanent meiofauna: observations on the feeding and behavior of selected taxa. Biol. Bull. 169: 397-416

Watzin, M. C. (1986). Larval settlement into soft-bottom systems: interactions with the meiofauna. J. exp. mar. Biol Ecol. 98: 65-113

Wilson, W. H. (1991). Competition and predation in marine softsediment communities. A. Rev. Ecol. Syst. 21: 221-241

Woodin, S. A. (1986). Settlement of infauna: larval choice? Bull. mar. Sci. 39: 401-407

Woodin, S. A. (1991). Recruitment of infauna: positive or negative cues? Am. Zool. 31: 797-807

Woodin, S. A., Marinelli, R. (1991). Biogenic habitat modification in marine sediments: the importance of species composition and activity. Symp. zool. Soc. Lond. 63: 231-250

Yingst, J. Y (1978). Patterns of micro- and meiofaunal abundances in marine sediments, measured with adenosine triphosphate assay. Mar. Biol. 47: 41-54

Yingst, J. Y., Rhoads, D. C. (1978). Seafloor stability in central Long Island Sound: part II. Biological interactions and their potential importance for seafloor erodibility. In Wiley, M. (ed.) Estuarine interactions. Academic Press, New York, p 245-260 